\title{
Improving the Masonry Brick Ductility using Mortar Bed Joint from Rubber Tire Crumbs: A Review
}

\author{
Restu Faizah, $^{1,2^{*}}$ Iman Satyarno, ${ }^{1}$ Henricus Priyosulistyo ${ }^{1}$ and Akhmad Aminullah ${ }^{1}$ \\ ${ }^{1}$ Department of Civil and Environmental Engineering, Universitas Gadjah Mada, \\ Yogyakarta, 55284 Indonesia \\ ${ }^{2}$ Department of Civil Engineering, Universitas Muhammadiyah Yogyakarta, \\ 55184 Indonesia \\ *Corresponding author: restu.faizah@mail.ugm.ac.id
}

Published online: 30 July 2018

To cite this article: Faizah, R. et al. (2018). Improving the masonry brick ductility using mortar bed joint from rubber tire crumbs: A review. J. Phys. Sci., 29(Supp. 2), 117-132, https://doi.org/10.21315/jps2018.29.s2.9

To link to this article: https://doi.org/10.21315/jps2018.29.s2.9

\begin{abstract}
Rubber tire waste is relatively difficult to be recycled into new tires. The volume of the tire wastes increases with the societal needs and time. Many efforts have utilised rubber tire wastes as an additional material in pavements, geotechnical work and concrete. However, a relatively small number of research works have been applying the wastes to improve the performance of masonry brick wall. This paper presents a review of previous studies on the application of rubber tire crumbs in structural elements and its possibilities to improve the performance of masonry brick walls. Many research works concluded that the rubber tire crumbs are potential materials in the mortar bed joint to increase the ductility of masonry brick wall. The use of rubber tire crumbs as mortar bed joint in masonry brick wall shows a large elastic deformation before failure. This paper recommends $60 \%$ of rubber tire crumbs in the mortar bed joint as an optimum amount to increase the ductility of masonry brick wall. At optimum amount, the mortar can be classified as lightweight concrete/mortar and meets the minimum requirement for the compressive strength of masonry wall. The review also recommends a laboratory experiment to study the contribution of mortar bed joint using rubber tire crumbs in loaddeflection behaviour and ductility of the masonry brick wall. A finite element model needs to be developed to have a general model of the masonry brick wall.
\end{abstract}

Keywords: Rubber tire crumbs, brick masonry walls, ductility, lightweight concrete, mortar bed joint 


\section{INTRODUCTION}

A number of giant earthquakes have been recorded in Indonesia from 2004 to 2009. The earthquakes triggered fatalities and severe structural damages, e.g., in Aceh (2004), Yogyakarta (2006), Bengkulu (2007), Padang (2009), Tasikmalaya (2009), etc. Satyarno reported that many masonry brick houses experienced severe damaged or collapsed during the Yogyakarta earthquake in 2006. ${ }^{1} \mathrm{~A}$ preliminary investigation found that the damages were due to brittleness of the masonry brick system, and the brick wall was not well constructed to have a unity structure to restrain earthquake loads, particularly horizontal loads. In general, the vulnerability of typical brick masonry wall houses in Indonesia is contributed by a few factors, including the following: low materials quality; absence of crucial elements; poor reinforcement details; modification of traditional houses; homes built on unstable ground; caused by fire; and others. ${ }^{1}$ Due to these reasons, the buildings were damaged and collapsed when earthquakes occured. From a field review, it can be known that most of the masonry-brick wall community houses were severely damaged and collapsed because those buildings have a high degree of vulnerability. ${ }^{2}$ In general, the vulnerability of a building is determined by the strength, stiffness, damping and ductility. These properties are predominantly determined by the quality of materials, available strength, quality of structure detailing, and the building configuration. ${ }^{3}$ Therefore, masonry brick houses should have adequate strength, stiffness, damping and ductility, so that the buildings can undergo a large degree of deformation before failure and will not collapse suddenly. The compressive strength of masonry-brick wall is highly influenced by the strength of mortar and the brick strength. In some cases, the addition of mortar strength no longer provides significant changes to the compressive strength of the brick masonry wall since the brick strength controls the strength. ${ }^{4}$

Rubber tire crumbs are typically a waste produced from the tire industry. In general, the rubber tires are hard to be recycled into a new tire. These wastes end up in the dump, with the amount increasing year after year. These wastes could be reused as a supplementary material in construction and materials technology. Previous studies investigated the use of rubber tire crumbs as an aggregate substitute for concrete and mortar to observe the properties of the composite which include specific weight, water absorption, density, flexural strength, compressive strength, modulus of elasticity and adhesion. Other studies used rubber tires in several sizes to replace fine aggregates and coarse aggregates. Two types of tire chips which have a dimension between $2 \mathrm{~mm}$ and $38 \mathrm{~mm}$ were used as coarse aggregates in Eldin and Senouci. ${ }^{5}$ Meanwhile, Sgobba used three broad categories of rubber tires for his study, i.e., chipped rubber, crumb rubber and ash rubber. ${ }^{6}$ Bekhiti et al. 
used three types of rubber tire powder with $1.6 \mathrm{~mm}, 1 \mathrm{~mm}$ and less than $0.08 \mathrm{~mm}$ dimension. ${ }^{7}$

This study explores the properties of rubber tire crumbs as an aggregate replacement from previous studies to estimate their effects on structural behaviour against earthquake loads. The outcome of this review is to establish a theoretical framework for the application of rubber tire crumbs as supplementary materials in mortar bed joint to improve the building response to earthquakes. Studies show that the masonry brick wall can be very brittle. Additionally, the rubber tire crumbs in the mortar bed joint is expected to increase the ductility of masonry brick wall.

\section{REVIEW OF PREVIOUS STUDIES}

\subsection{Rubber Tire Crumbs}

Rubber tire crumbs are made from used rubber tires which are easy to get in Indonesia with price ranging from Rp. 1,400/ kg to Rp. 11,000/kg, depending on the dimension of the granules, in which smaller grains will have a higher price. Figure 1 shows three broad categories of wasted rubber tires: (a) shredded/chip rubber having a dimension of about $25-30 \mathrm{~mm}$; (b) crumb rubber which is highly irregular, in the range of 3-10 $\mathrm{mm}$; and (c) ash rubber having a dimension smaller than $1 \mathrm{~mm} .^{6}$

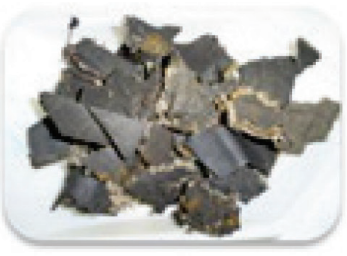

(a)



(b)

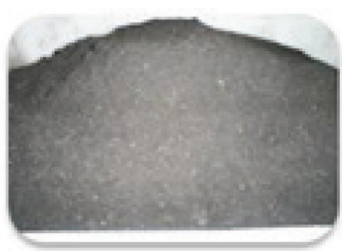

(c)

Figure 1: Three broad categories of wasted rubber tires. ${ }^{6}$

The properties of wasted rubber tires which are different in shape, weight, size and proportion of components in the base mixture are shown in Table $1 .^{6}$ 
Table 1: The properties of rubber tires."

\begin{tabular}{lccc}
\hline \multirow{2}{*}{ Property } & \multicolumn{3}{c}{ Laboratory designation } \\
\cline { 2 - 4 } & chips & crumb & ash \\
\hline Finess modulus & 7.65 & 6.2 & 2.02 \\
Maximum size $(\mathrm{mm})$ & 25.0 & 14.0 & 1.0 \\
Gradation class & $12.5-25$ & $2.5-4$ & $0-1$ \\
Average bulk volume mass $\left(\mathrm{kg} \mathrm{m}^{-3}\right)$ & $1.12 \pm 0.092$ & $1.12 \pm 0.021$ & $1.09 \pm 0.024$ \\
\hline "truck rubber tires & & &
\end{tabular}

Table 2: Rubber powder characteristics. ${ }^{7}$

\begin{tabular}{ll}
\hline Properties & Rubber powder \\
\hline Density & 0.83 \\
Size & $80 \mu \mathrm{m}-1.6 \mathrm{~mm}$ \\
Elongation & $420 \%$ \\
Rate of steel fiber & $0 \%$ \\
\hline
\end{tabular}

Bekhiti investigated the physical characteristics of rubber tires having various dimensions from $1.6 \mathrm{~mm}$ to $0.8 \mathrm{~mm}$ with an average particle size of $1 \mathrm{~mm}$ which gives a result as shown in Table $2 .{ }^{7}$ He also considers the chemical characteristics of rubber tires, i.e., rubber $(54 \%)$, carbon black $(29 \%)$, textile $(2 \%)$, oxidise zinc $(1 \%)$, sulfur (1\%) and additives (13\%).

\subsection{The Performance of Masonry Brick Wall Houses}

Masonry brick wall is a composite construction consisting of masonry units and mortar as bed joint, in which the earthquake response of brick masonry walls depends on the relative strengths of brick and mortar. ${ }^{8}$ For satisfactory performance during earthquake, a structure must have strength as well as ductility. A ductile structure can enhance the structural stability of earthquake resistance and can undergo large strain while resisting loads. ${ }^{9}$ Whereas, the masonry structure is most vulnerable during an earthquake mainly due to the brittle and large mass properties. ${ }^{10}$ In severe earthquakes, masonry wall structures may collapse and cause casualties. Structures with adequate ductility will last longer against earthquakes and can undergo large deformation before failure, and the structure will not collapse suddenly. Typical load-displacement relationship of the masonry walls is shown by Raharjo in Figure $2 .{ }^{11}$ 


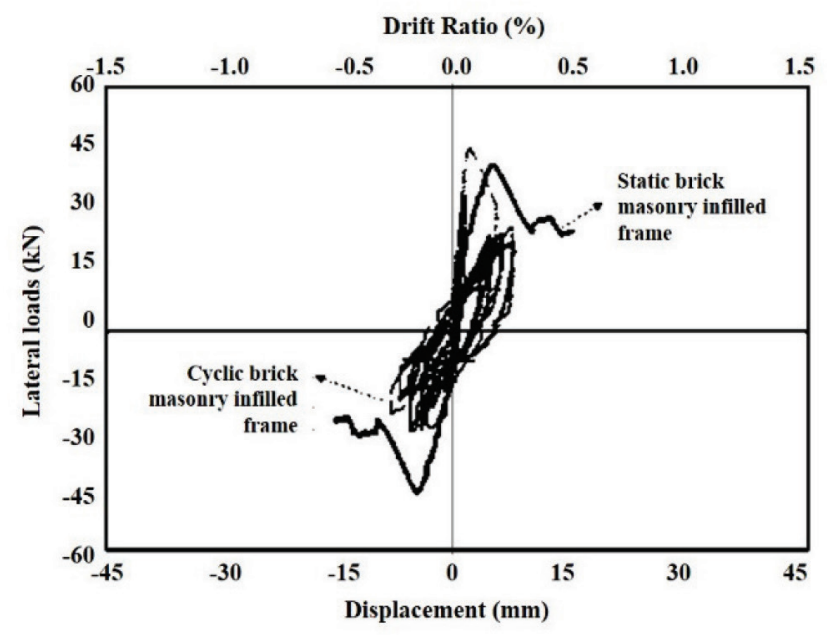

Figure 2: Typical load-displacement relationship. ${ }^{11}$

The curve in Figure 2 shows that the brittle behaviour characterised by lateral deformation after reaching maximum loads is very short, whereas the ductile behaviour will have an elongation curve on the deformation axis. Paulay and Priestley stated that ductility is the capacity of a structure or its members to undergo a large inelastic deformation beyond the initial yield deformation without losing much of its load carrying capacity or without rupture before failure. ${ }^{9,12}$ Ductility $(\mu)$ is defined by a ratio of the total imposed displacements at the ultimate state $(\Delta u)$ to that at the onset of yield $(\Delta y)$ shown in Equation $1::^{12}$

$$
\text { Ductility }=\frac{\Delta u}{\Delta y}
$$

where $\Delta u$ is the total imposed displacements at the ultimate state (mm), and $\Delta y$ is the total imposed displacements at the onset of yield ( $\mathrm{mm})$.

Equation 1 shows that ductility $(\mu)$ will increase if the total imposed displacements at the ultimate state $(\Delta u)$ is much bigger than at the onset of yield $(\Delta y)$. Therefore, the efforts to increase brick masonry wall ductility means to increase the displacement at the ultimate state by using more ductile materials.

A typical damage type of masonry wall under earthquake is an out-of-plane failure and in-plane failure. Out-of-plane failure mode develops due to the load acting perpendicular to the wall plane which might cause the form of two cross-inclined lines, while in-plane failure is caused by in-plane seismic loads acting along in the plane of the wall characterised by distributed diagonal cracking in the walls. ${ }^{13}$ 
There are three possible in-plane failure modes, i.e., shear failure, sliding mode and flexural (rocking) mode. Figure 3(a) shows the stair-step through bed joints due to strong bricks and weak mortars. They pass through the bricks in case of weak bricks and strong mortars. In the case of low vertical loads and low friction coefficient, which may be due to poor quality mortar, horizontal cracks in the bed joints will form as shown in Figure 3(b). Figure 3(c) shows the failure is obtained by overturning of the wall. ${ }^{14}$

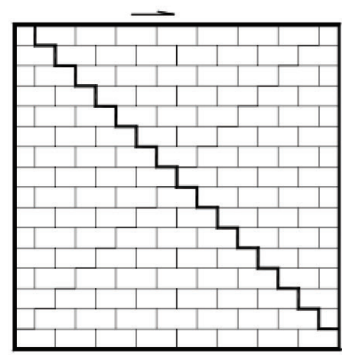

(a)



(b)

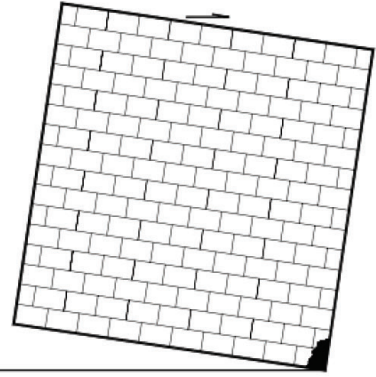

(c)

Figure 3: Three possible in-plane failure modes: (a) shear failure, (b) sliding mode, and (c) flexural (rocking) mode. ${ }^{14}$

\subsection{Performance of Mortar with Rubber Tire Crumbs}

Research on mortar with rubber tire crumbs has been carried out for many years to examine the potential utilisation of wasted tires in concrete production. Previous studies have examined concrete more than mortar, but their results may be taken as considerations to the mortar used. The performance of either concrete/mortar with wasted rubber tire crumbs is described in the subsequent discussion.

\subsubsection{Specific weight}

Satyarno reported that the unit weight of concrete with rubber tire crumbs decrease gradually with the increasing of rubber content. ${ }^{15}$ To meet the requirement for lightweight concrete of $1800 \mathrm{~kg} \mathrm{~m}^{-3}$, the mixture required at least $40 \%$ rubber content. Sadek and Attar added $60 \%$ rubber to obtain a unit weight of $1780 \mathrm{~kg} \mathrm{~m}^{-3}$ for lightweight concrete. ${ }^{16}$ Furthermore, the specific weight for rubber concrete can be classified as lightweight concrete, so it is suitable to use it as a building material that is more resistant to earthquakes. The use of lighter materials makes the weight of the structure also lighter. This phenomenon results in small base shear, base story shear and story drift. ${ }^{17}$ These characteristics improve the 
building response to the earthquake. Other studies also show similar results, e.g., Batayneh, Pitta and Onkar. ${ }^{18-20}$

\subsubsection{Mechanical characteristics}

Several studies indicated that the use of rubber tire crumbs reduced the compressive, tensile and flexural strengths. ${ }^{20-26}$ Increasing the amount of the rubber crumb will result in further decrease in strength properties. The strength reduction is attributed to the weak bonding between the rubber particles and the cement matrix. ${ }^{27}$ Meanwhile, Batayneh shows the effects of rubber tire crumbs content on various strength results that can be seen in Table $3 .^{18}$

Table 3: The effect of rubber tire crumbs content on various strength results in. ${ }^{18}$

\begin{tabular}{cccc}
\hline $\begin{array}{c}\text { Rubber crumb } \\
\text { content }(\%)\end{array}$ & $\begin{array}{c}\text { Flexural strength } \\
(\mathrm{MPa})\end{array}$ & $\begin{array}{c}\text { Tensile strength } \\
(\mathrm{MPa})\end{array}$ & $\begin{array}{c}\text { Compressive strength } \\
(\mathrm{MPa})\end{array}$ \\
\hline 0 & 3.8 & 2.820 & 25.330 \\
20 & 2.550 & 1.840 & 18.960 \\
40 & 2.040 & 1.470 & 12.270 \\
60 & 1.380 & 0.940 & 8.070 \\
80 & 0.770 & 0.533 & 4.470 \\
100 & 0.640 & 0.220 & 2.500 \\
\hline
\end{tabular}

Table 3 shows that with the increase in the content of rubber tire crumb, the strength of composites decreased. As a result, if used rubber tire crumbs are used as a material replacement in cement-based composites, the minimum strength required must be considered, as shown by Neville. ${ }^{28}$ The required compressive strength for the different application categories of the lightweight structural concrete (LWC) can be seen in Table 4.

Table 4: The practical range of categories of lightweight concrete. ${ }^{28}$

\begin{tabular}{lll}
\hline Categories & $\begin{array}{l}\text { Density range } \\
\left(\mathrm{kg} \mathrm{m}^{-3}\right)\end{array}$ & Minimum strength (MPa) \\
\hline Structural lightweight concrete & $1350-1900$ & 17 \\
Moderate strength concrete & $1900-800$ & $7-17$ \\
Low-density concrete & $300-800$ & $\begin{array}{l}\text { Used for structural purposes } \\
\text { (insulation panel, pavement, } \\
\text { blocks, etc.) }\end{array}$ \\
\hline
\end{tabular}

Table 4 shows that the minimum strength required for lightweight structural concrete is $17 \mathrm{MPa}$. As indicated in Table 3, the addition of $20 \%$ rubber tire crumbs in the mixture, the average strength is $18.96 \mathrm{MPa}$. Batayneh concluded that the 
concrete containing up to $20 \%$ rubber tire crumbs could be used as lightweight structural elements. ${ }^{18}$

For the content of rubber tire crumbs, to obtain the minimum requirement compressive strength of $2.5 \mathrm{MPa}$, the rubber must be limited up to $60 \%$ for $350 \mathrm{~kg}$ $\mathrm{m}^{-3}$ of cement content and $80 \%$ for $400 \mathrm{~kg} \mathrm{~m}^{-3}$ of cement content. ${ }^{15}$ Also, Table 3 shows that specimens with $100 \%$ rubber crumb content have compressive strength beyond the requirement of masonry strength which is $2.5 \mathrm{MPa} .{ }^{18}$

\subsubsection{Modulus of elasticity}

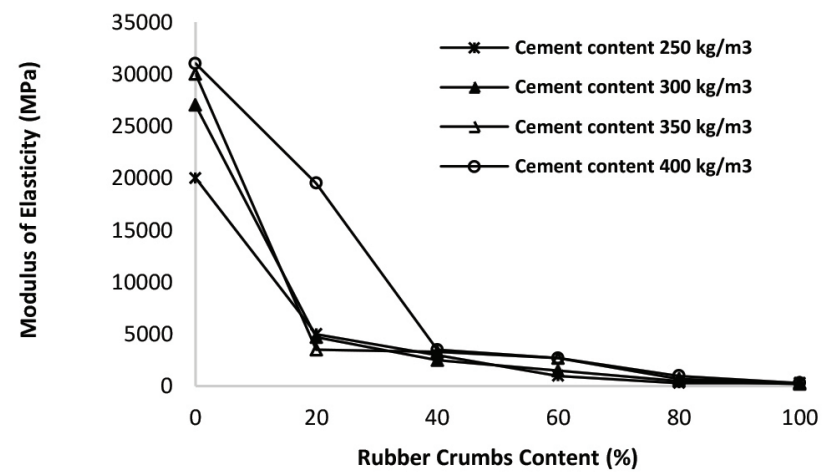

Figure 4: The relationship between rubber tire crumbs and modulus of elasticity of concrete. ${ }^{15}$

Satyarno reports that the modulus of elasticity tends to decrease with increased addition of recycled rubber aggregate, as shown in Figure $4 .{ }^{15}$ This result is similar to other studies. ${ }^{23,27,29,30}$ The studies found that the reduction of the modulus of elasticity results in the production of more ductile materials.

\subsubsection{Stress and strain relationship}

The relationship between stress and strain is shown in Figure 5 for different rubber tire crumb contents in the concrete mix. It can be seen that the increase of the rubber crumb content results in a decrease of strength properties, but the concrete becomes more ductile. ${ }^{15}$ Similarly, Batayneh states that concrete with a higher percentage of rubber tire crumbs possesses high toughness since the generated energy is mainly plastic. ${ }^{18}$ 


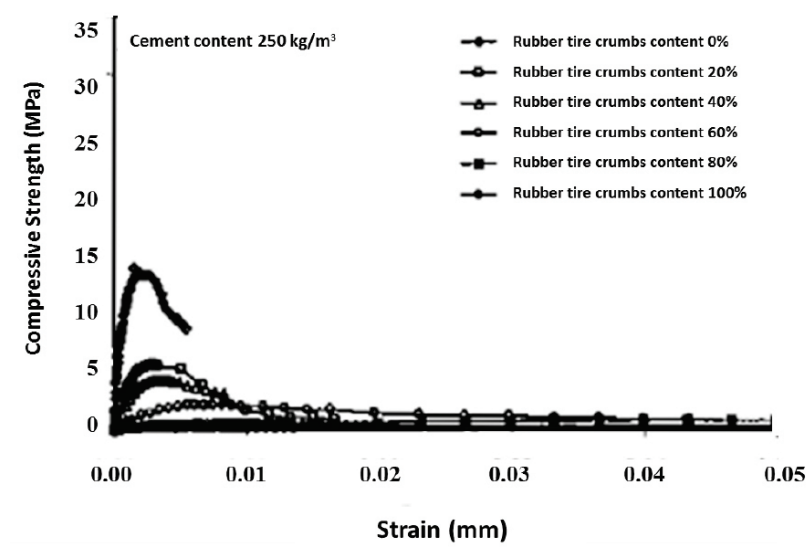

Figure 5: Relationship between stress and strain for different rubber contents. ${ }^{15}$

\subsubsection{Mode of tension failures}

The characteristics of ductile materials can be seen on the result of laboratory tests as shown in Figure 6. ${ }^{5}$ The failure of specimens in tension, likewise, is not a brittle failure. The specimens experience a ductile mode of failure and exhibit the high capability of absorbing plastic energy. The concrete mass can withstand loads even when it is highly cracked. The specimens never separate into two halves under splitting tension loading.

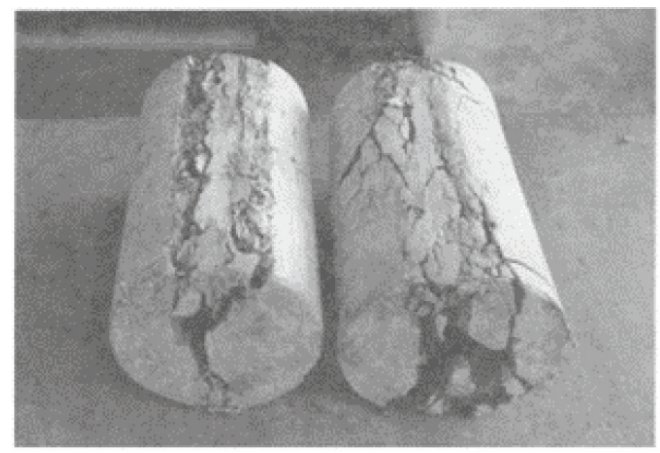

Figure 6: Concrete with rubber tire crumbs after testing. ${ }^{5}$ 


\section{DISCUSSION}

Brick masonry walls have brittle properties and a large mass, so it is necessary to think of some efforts to increase brick masonry wall ductility and keep them lightweight. Several previous studies have tested concrete/mortar using rubber tire crumbs as a partial replacement material of aggregates and resulted in the properties of rubbers and concrete/mortar. Rubber tire crumbs are one of the wasted materials that are hard to be recycled as the amount increases, so the use of the material is expected to be a solution to environmental problems. There are some important considerations to estimate possibilities of rubber tire crumbs to be used in mortar bed joint to increase brick masonry wall ductility.

Several previous studies indicated that the use of rubber tire crumbs reduced mechanical characteristics of concrete/mortar. ${ }^{20-26}$ It should be noted, however, that the compressive strength of brick masonry walls is not only influenced by the strength of the mortar but also limited by the strength of the brick. Sometimes the addition of mortar strength no longer gives significant changes to the compressive strength of brick masonry walls. ${ }^{4}$ With these considerations, the role of rubber tire crumbs to improve the brick masonry wall ductility can be applied by using the minimum requirement of compressive strength for masonry which is $2.5 \mathrm{MPa}$.

\subsection{Application of the Rubber Tire Crumbs in Mortar Bed Joint}

From the relationship between stress and strain for different rubber contents (Figure 5), it can be explained that the concrete ability to deform among several kinds of rubber tire crumbs content. The concrete with $0 \%$ rubber tire crumbs content will cause failure at the shortest strain, and additional rubber tire crumbs in concrete results in more extended deformation. The addition of rubber tire crumbs content increases the material's ability to support loads even after the formation of cracks; this means that the structure's ductility increases.

The application of mortar containing rubber tire crumbs as mortar bed joint may increase brick masonry wall ductility so that the walls are more resistant to earthquakes. When portals receive horizontal forces at floor levels under earthquake shakes, they try to move in the horizontal direction. Earthquake shaking reverses tension and compression in members as shown in Figure $7 .{ }^{31}$ In this condition, masonry walls move together with the columns. If the walls have brittle properties, they will develop cracks once their ability to carry horizontal load is exceeded, and maybe the wall can fall out-of-plane in the further event. One of the solutions to increase masonry resistance after cracks is by increasing the ductility, particularly 
mortar bed joint ductility because bed-joint damage happens more frequently than brick unit damage.

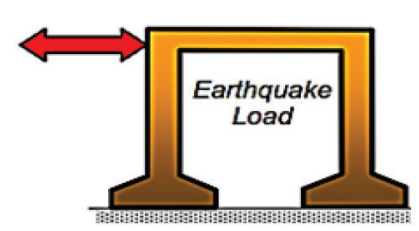

(a)

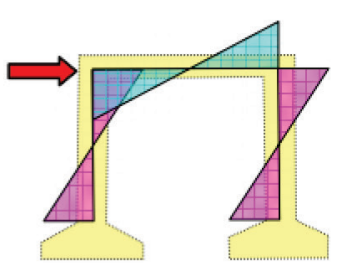

(b)

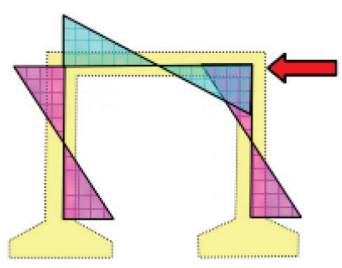

(c)

Figure 7: The structure movement under horizontal force. ${ }^{31}$

\subsection{Optimum Content of Rubber Tire Crumbs}

Used rubber tire crumbs as a substitute material in mortars decrease the compressive, tensile, flexural strengths and modulus of elasticity in concrete or mortar. The rubber contents and dimension must be considered maximally to get the adequate strength. From the previous studies, several results can be taken as considerations as follows:

1. The rubber tire crumb content, to obtain the compressive strength of concrete through the minimum requirement of compressive strength for masonry of $2.5 \mathrm{MPa}$, must be limited to up to $60 \%$ according to Satyarno and $100 \%$ according to Batayneh. ${ }^{15,18}$

2. To get the lightweight concrete with unit weight which is less than 1,800 $\mathrm{kg} \mathrm{m}^{-3}$, it needs more than $40 \%$ rubber in the concrete. ${ }^{15}$

3. The lightweight concrete $\left(1,780 \mathrm{~kg} \mathrm{~m}^{-3}\right.$ unit weight) can be obtained at $60 \%$ rubber content. ${ }^{15}$

4. Batayneh concluded that the modified concrete containing up to $20 \%$ rubber tire crumb could be used in lightweight structural elements. ${ }^{18}$

The data of the previous studies are given in Table 5 . 
Table 5: The suggested rubber tire crumb contents.

\begin{tabular}{|c|c|c|c|c|}
\hline \multicolumn{2}{|c|}{$\begin{array}{l}\text { Suggested rubber } \\
\text { tire crumb content }\end{array}$} & \multirow[t]{2}{*}{ Source } & \multirow[t]{2}{*}{ Reasons } & \multirow[t]{2}{*}{ Applications } \\
\hline Min & Max & & & \\
\hline & $60 \%$ & 15 & $\begin{array}{l}\text { To ensure its compressive strength beyond } \\
\text { the requirement of masonry strength } \\
\text { which is } 2.5 \mathrm{MPa} \text { (for } 350 \mathrm{~kg} \mathrm{~m}^{-3} \text { cement } \\
\text { content). }\end{array}$ & Masonry \\
\hline & $100 \%$ & 18 & $\begin{array}{l}\text { To ensure its compressive strength beyond } \\
\text { the requirement of masonry strength } \\
\text { which is } 2.5 \mathrm{MPa} \text {. }\end{array}$ & Masonry \\
\hline $60 \%$ & & 16 & $\begin{array}{l}\text { To get the lightweight concrete at the unit } \\
\text { weight of } 1,780 \mathrm{~kg} \mathrm{~m}^{-3}\end{array}$ & $\begin{array}{l}\text { Lightweight } \\
\text { concrete }\end{array}$ \\
\hline $40 \%$ & & 15 & $\begin{array}{l}\text { To get the lightweight concrete with unit } \\
\text { weight which is less than } 1,800 \mathrm{~kg} \mathrm{~m}^{-3} \\
\text { (maximum constraint of unit weight the } \\
\text { lightweight concrete) }\end{array}$ & $\begin{array}{l}\text { Lightweight } \\
\text { concrete }\end{array}$ \\
\hline \multirow[t]{2}{*}{$60 \%$} & & 15 & $\begin{array}{l}\text { To obtain the lightweight concrete }(1,780 \\
\left.\mathrm{kg} \mathrm{m}^{-3} \text { unit weight }\right)\end{array}$ & $\begin{array}{l}\text { Lightweight } \\
\text { concrete }\end{array}$ \\
\hline & $20 \%$ & 18 & $\begin{array}{l}\text { Rubber tire crumbs can be used in } \\
\text { lightweight structural elements. }\end{array}$ & $\begin{array}{l}\text { Lightweight } \\
\text { structural element }\end{array}$ \\
\hline
\end{tabular}

From Table 5, it can be concluded that the most appropriate calculation for used rubber tire crumbs to be included in mortar bed joint to increase the ductility is $60 \%$, because they are qualified as lightweight concrete/mortar, and they can pass over the minimum compressive strength of masonry.

\subsection{Model for Future Studies}

Previous studies have shown many laboratory investigations on the application of rubber tire crumbs in concrete technology. However, these studies are limited to material testing such as compressive and tensile strength tests of the concrete cubes or cylinders. ${ }^{5,18,23,27}$ No study has been conducted to apply the rubber tire crumbs as supplementary material in a mortar and its application in masonry brick wall. Therefore, further studies are needed to investigate the strength and ductility properties of mortar containing rubber tire crumbs, and ductility behaviour of masonry brick wall. A laboratory model of a brick wall can be carried out to obtain the ductility behavior by applying a horizontal loading system as designed in Figure $8 .{ }^{11} \mathrm{~A}$ specimen of the masonry wall is fabricated with various rubber tire crumb content in the bed joint to determine the load-deflection behaviour of the wall. 
The model test will produce load-deflection curve and typical cracks propagation for various walls type. The typical curve and crack pattern will determine the degree of ductility of the walls. To obtain a general masonry brick wall behaviour, the laboratory test needs to be verified using a finite element analysis. A computer software, Abaqus or other programs can be used to model and to verify the laboratory model test.

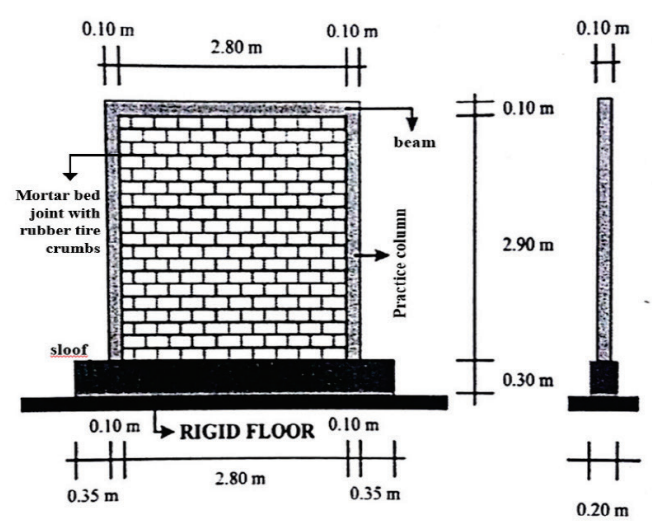

(a)

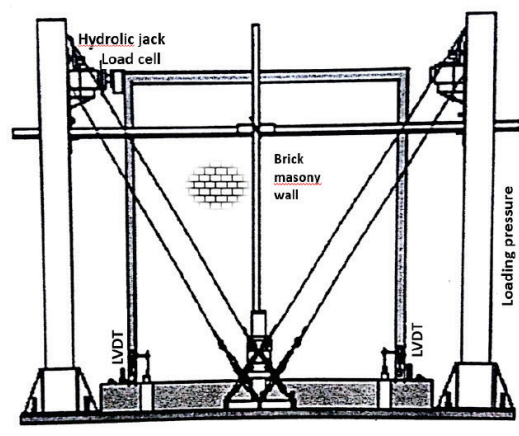

(b)

Figure 8: The loading set up of (a) specimen of the wall,'(b) loading frame set up. ${ }^{11}$

\section{CONCLUSION}

A review of previous studies on the potential use of rubber tire crumb in structure and concrete technology has been presented. In general, rubber tire crumb is categorised as lightweight materials. Thus, the material is beneficially used in lightweight concrete and earthquake resistant building. Some findings from the review can be noted that rubber tire crumbs have a high potential to be used as a substitution material in the mortar bed joint to increase the ductility of masonry brick wall because of the ability to undergo a large elastic deformation before failure. The recommendation of used rubber tire crumb content in the mortar bed joint to increase brick masonry wall ductility is $60 \%$, to be qualified as lightweight concrete/mortar and to pass over the minimum compressive strength of masonry. ${ }^{15,16}$ As for structural elements, rubber tire crumb contents should not exceed $20 \%$ of the total aggregate volume. ${ }^{18}$ Further studies need to be carried out in the laboratory to model the load-deflection of the brick wall by applying a horizontal loading system. The model needs to be verified by a finite element analysis to obtain a general load-deflection model of masonry-brick wall. 


\section{ACKNOWLEDGEMENTS}

The authors express their gratitude and highest appreciation to the Lembaga Pengelola Dana Pendidikan (LPDP) from the Ministry of Finance Indonesia with the Beasiswa Unggulan Dosen Indonesia-Dalam Negeri (BUDI-DN) scholarship. Support from Universitas Muhammadiyah Yogyakarta, Indonesia is also highly appreciated. The authors also acknowledge the proofreading assistance by Professor Agus Setyo Muntohar, Department of Civil Engineering, Universitas Muhammadiyah Yogyakarta.

\section{REFERENCES}

1. Satyarno, I. (2011). Vulnerability of Indonesian community houses to earthquake disaster. Yogyakarta: Star Publisher.

2. Satyarno, I. (2007). Some practical aspects in the post Yogyakarta earthquake reconstruction of brick masonry houses in the Yogyakarta earthquake of May 27, 2006. Yogyakarta: Star Publisher.

3. Satyarno, I (2010). Evaluasi dan tindakan pengurangan kerentanan bangunan dalam rangka mitigasi bencana gempa. Pidato pengukuhan Jabatan Guru Besar pada Fakultas Teknik Universitas Gadjah Mada (UGM), Yogyakarta. Fakultas Teknik UGM, Yogyakarta.

4. Wisnumurti, Soehardjono, A. \& Palupi, K. A. (2007). Optimalisasi penggunaan komposisi campuran mortar terhadap kuat tekan dinding pasangan bata merah. J. Rek. Sipil, 1(1), 25-32.

5. Eldin, N. \& Senouci, A. B. (1993). Rubber-tire particles as concrete agregate. J. Mater. Civ. Eng., 5, 478-496.

6. Sgobba, S. et al. (2010). Use of rubber particles from recycled tires as concrete aggregate for engineering applications. Paper presented at the Second International Conference on Sustainable Construction Materials and Technologies, Universita Politecnica Delle Marce, Ancona, Italy, 28-30 June.

7. Bekhiti, M., Trouzine, H. \& Asroun, A. (2014). Properties of waste tire rubber powder. Eng. Tech. Appl. Sci. Res., 4(4), 669-672.

8. Murty, C. (2003). How to make buildings ductile for good seismic performance. IITK-BMTPC-Earthquake Tip, Learning Earthquake Design and Construction, 9.

9. Pawar, N. P., Rajguru, R. \& Mehetre, P. (2015). Ductility requirements of earthquake resistant reinforced concrete buildings. Int. J. Innov. Eng. Sci. Tech., 1(1), 1-5. 
10. Coburn, A. \& Spence, R. (2002). Earthquake protection, 2nd ed. London: John Wiley \& Sons.

11. Raharjo, E. (2005). Post plastic characteristic of brick masonry wall with horizontal reinforcement under cyclic horizontal force (in Indonesia). Master diss., Universitas Gadjah Mada, Indonesia.

12. Paulay, T. \& Priestley, M. (1992). Seismic design of reinforced concrete and masonry buildings. Montreal: John Wiley \& Sons.

13. Maheri, M. R. \& Najafgholipour, M. A. (2012). In-plane shear and out-ofplane bending capacity interaction in brick masonry walls. Paper presented at 15th World Conference on Earthquake Engineering. Lisbon, Portugal, 2428 September.

14. ElGawady, M., Lestuzzi, P. \& Badoux, M. (2002). Dynamic in-plane behavior of URM wall upgraded with composites. Paper presented at the 3rd International Conference on Composites in Infrastructure, ICCI'02, Sanfransisco, June.

15. Satyarno, I. (2006). Penggunaan serutan karet ban bekas untuk campuran beton. J. Med. Tek., 28(4), 45-51.

16. Saddek, D. \& El-Attar, M. (2015). Structural behavior of rubberized masonry walls. J. Clean. Prod., 89, 174-186.

17. Faizah, R. (2013). Analisis distribusi vertikal gaya gempa dan implikasinya pada respons bangunan bertingkat. Master diss., Universitas Islam Indonesia, Indonesia.

18. Batayneh, M., Marie, I. \& Asi, I. (2008). Promoting the use of crumb rubber concrete in developing countries. J. Waste Manag., 28, 2171-2176.

19. Pitta, K., Setyo, N. I. \& Haryanto, Y. (2010). Pengaruh jumlah dan ukuran potongan ban karet berbentuk kubus sebagai substitusi agregat kasar terhadap modulus elastisitas beton. Unpublished paper, Universitas Jenderal Soedirman, Indonesia.

20. Onkar, C. et al. (2016). Effect of replacement of coarse aggregate by scrap tyre. Int. Res. J. Eng. Tech., 3(5), 1119-1122.

21. Yang, S., Lohner, S. \& Kjartanson, B. (2002). Mechanical properties of shredded tires. Geo. Test. J., 25(1), 44-52.

22. Siddique, R. \& Naik, T. (2004). Properties of concrete containing scrap-tire rubber: An overview. Waste Manag., 24, 563-569.

23. Jevtic, D., Zakic, D. \& Savic, A. (2012). Investigation of cement based composites made with recycled rubber aggregate. Sci. Pap. Hem. Ind., 66(4), 609-617.

24. Boudaoud, Z. \& Beddar, M. (2012). Effects of recycled tires rubber aggregates on the characteristics of cement concrete. OJ Civ. Eng.-Sci. Res., 2, 193-197. 
25. Akinwonmi, Samuel, A. \& Emmanuel, S. (2013). Mechanical strength of concrete with crumb and shredded tyre as aggregate replacement. Int. J. Eng. Res. Appl., 3(2), 1098-1101.

26. Fiore, A. et al. (2014). On the fresh/hardened properties of cement composites incorporating rubber particles from recycled tires. Hind. Publ. Corp. Adv. Civ. Eng., 1-12.

27. Oikonomou, N. \& Mavridou, S. (2009). The use of waste tyre rubber in civil engineering works. Sust. Const. Mat., 213-238.

28. Neville, A. (2011). Properties of concrete, 5th ed. London: Pearson.

29. Albano, C. et al. (2005). Influence of scrap rubber addition to Portland I concrete composites: Destructive and non-destructive testing. Comp. Str., 71, 439-446.

30. Khaloo, A., Dehestani, M. \& Rahmatabadi, P. (2008). Mechanical properties of concrete containing a high volume of tire-rubber particles. Waste Manag., 28, 2472-2482.

31. Murty, C. (2003). How do earthquakes affect reinforced concrete buildings? IITK-BMTPC - Learning Earthquake Design and Construction, 17, 2. 